(c) American Dairy Science Association, 2003.

\title{
Responses of Holstein Cows to a Low Dose of Somatotropin (bST) Prepartum and Postpartum ${ }^{1}$
}

\author{
M. S. Gulay, ${ }^{\star}$ M. J. Hayen, ${ }^{\star}$ L. C. Teixeira,† C. J. Wilcox, ${ }^{\star}$ and H. H. Head ${ }^{\star}$ \\ *Department of Animal Sciences, University of Florida, Gainesville \\ †Department de Zootecnia, UFLA, Lavras, Brazil
}

\begin{abstract}
Objectives were to evaluate the effects of a low dose of bovine somatotropin (bST) injected prepartum and postpartum on body condition score (BCS), body weight (BW), and milk yield (MY) in cows as well as somatotropin insulin, insulin-like growth factor-I (IGF-I), glucose, and nonesterified fatty acids (NEFA) in plasma. Holstein cows nearing second or later parities were assigned randomly to control $(\mathrm{CON}=98)$ or bST-treated $($ TRT $=95)$ groups. Biweekly injections of bST began $21 \pm 3 \mathrm{~d}$ before expected calving and continued through $42 \mathrm{~d}$ postpartum (CON vs. TRT; 0 vs. $10.2 \mathrm{mg}$ of bST/ d). From 42 to $100 \mathrm{~d}$ postpartum, no cows received bST. During yr 1, somatotropin, IGF-I, insulin, NEFA, and glucose were measured in plasma samples from 82 cows. During yr 2, effects of bST on BCS and BW of 111 cows were evaluated, but no blood samples were collected. Milk yields through $100 \mathrm{~d}$ of all 193 cows were analyzed. Prepartum treatment with bST resulted in greater prepartum plasma concentrations of somatotropin, insulin, and numerically greater NEFA but did not affect glucose or IGF-I. Postpartum bST increased mean plasma concentrations of somatotropin and NEFA, but not INS, IGF-I, or glucose. Mean BCS of cows did not differ prepartum, around parturition, or postpartum. Although mean BW did not differ prepartum or around calving, cows receiving bST maintained greater BW postpartum. Cows receiving bST tended to have higher MY $(6.6 \%)$ in the first $60 \mathrm{~d}$ of lactation, but differences did not persist through $100 \mathrm{~d}$, including 40 $d$ when no cows received bST. Number of cows that were culled due to health $(\mathrm{CON}=3 \mathrm{vs}$. TRT $=2)$ or died $(\mathrm{CON}=3 \mathrm{vs} . \mathrm{TRT}=1)$ were not affected by treatment. Low doses of bST in the transition period resulted in higher postpartum BW, quicker recovery of body condition during lactation, and significantly more milk during treatment.
\end{abstract}

Received March 5, 2003.

Accepted May 23, 2003.

Corresponding author: H. H. Head; e-mail: head@animal.ufl.edu.

${ }^{1}$ Florida Agricultural Experiment Station Journal Series No. R09349.
(Key words: transition period, dairy cow, bST, milk yield)

Abbreviation key: $\mathbf{C M O}=$ calving month, $\mathbf{C O N}=$ control group, $\mathbf{M Y}=$ milk yield, $\mathbf{N E B}=$ negative energy balance, $\mathbf{P C}=$ pyruvate carboxylase, $\mathbf{T R T}=$ bST-injected group.

\section{INTRODUCTION}

Dairy cows receiving injections of bST during lactation have enhanced milk production. Typical milk yield (MY) increases are at least 10 to $15 \%$ but often are greater with better care and management of the cows (Bauman et al., 1985). During the first days of bST treatment, MY increases gradually and reaches a peak, and the increase is maintained with continuous injections of bST (Bauman, 1999).

Although increased MY responses typically are found when cows receive bST beyond $60 \mathrm{~d}$ postpartum, small increases in MY have been observed when low doses of bST were given during prepartum and/or early postpartum periods. However, most studies (Stelwagen et al., 1991; Bachman et al., 1992; Simmons et al., 1994; Eppard et al., 1996) failed to show an increase in MY when bST was injected prepartum but not postpartum. In contrast, Putnam et al. (1999) reported a significant effect of prepartum bST on milk production during early lactation, which appeared to increase as lactation progressed. Postpartum injections of bST soon after calving also gave inconsistent results.

It has been hypothesized that a low dose of bST injected during the transition period would improve the overall performance of a cow, especially during early lactation (Garcia et al., 2000; Gulay et al., 2000), without the negative effects seen when greater doses were used (Eppard et al., 1996). Generally, cows receiving a full dose of bST (POSILAC, $500 \mathrm{mg}$ ) during the early postpartum decreased BCS more during postpartum, and conception rate was affected adversely compared with cows not receiving bST (Moallem et al., 1997, 2000). When bST ( 5 and $14 \mathrm{mg} / \mathrm{d}$ ) was injected into cows during the $46 \mathrm{~d}$ before parturition, DMI tended to be about $3 \mathrm{~kg} / \mathrm{d}$ greater after parturition, and the response 
after several weeks of injection seemed to be dose dependent (Simmons et al., 1994). During previous studies, cows receiving prepartum and postpartum injections of 10.2 or $15.3 \mathrm{mg}$ of $\mathrm{bST} / \mathrm{d}$ showed increased concentrations of somatotropin, IGF-I, and triiodothyronine in plasma (Gulay et al., 2000), and bST-treated cows recovered BCS more rapidly during early lactation. Cows injected with $15.3 \mathrm{mg}$ of $\mathrm{bST} / \mathrm{d}$ also produced numerically greater daily milk and $3.5 \%$ FCM yields. However, in that study animal numbers (five to seven per group) were too small to detect effects of bST dose on milk production.

In the present study, the effects of a low dose of bST (10.2 $\mathrm{mg}$ of bST/d) during both the prepartum and postpartum periods were examined using a larger number of cows. Major objectives were to evaluate the effects of a low dose of bST on DMI, BCS, and BW both prepartum and postpartum; to evaluate the overall yield of milk during lactation; and to determine any adverse or positive effects on health of the cows.

\section{MATERIALS AND METHODS}

Holstein cows $(n=193)$ were used in an experiment conducted over a 2-yr period following the protocol approved by the Institutional Animal Care and Use Committee of the University of Florida. Cows were assigned randomly about 4 wk before expected calving date. Ages of the cows ranged from 3 to $6 \mathrm{yr}$, with parities between 1 and 5. Information on the animals, including parity and age, date of expected calving, days dry, and milk yields during previous lactation were obtained from the dairy research farm records. Actual number of days that cows were sampled prepartum ( $21 \pm 10 \mathrm{~d})$ differed from expected because of early or late calving. All cows were maintained on experiment for at least $100 \mathrm{~d}$ postpartum and received no other treatments during that period.

During yr 1, blood samples were collected from 82 cows [control $(\mathbf{C O N}=41)$ vs. injected $(\mathbf{T R T}=41)$ ] that calved between October 1998 and January 1999. During yr 2, effects of bST on BCS and BW of 111 cows (CON $=57$ vs. $\mathrm{TRT}=54)$ that calved between October 1999 and March 2000 were evaluated, but no blood samples were collected.

\section{bST Treatments}

A sterile prolonged-release injectable formulation of a recombinant DNA derived bST analogue (POSILAC, $500 \mathrm{mg}$ in $1.4 \mathrm{ml}$; Monsanto, St. Louis, MO) was used for injections. Cows were assigned randomly to one of two treatment groups, $\mathrm{CON}(\mathrm{n}=98)$, which received no bST, whereas those in TRT $(n=95)$ received subcutane-
Table 1. Dry matter concentrations and chemical composition of close-up dry (CUD) ration and TMR with whole cottonseeds fed to Holstein cows. ${ }^{1}$

\begin{tabular}{lcr}
\hline & \multicolumn{2}{c}{$\%$ DM } \\
\cline { 2 - 3 } Ingredients & CUD & TMR \\
\hline Corn silage & 37.12 & 21.72 \\
Alfalfa hay & $\ldots$ & 9.14 \\
Cottonseed hulls & $\ldots$ & 5.57 \\
Citrus pulp & $\ldots .24$ & 9.94 \\
Hominy & 7.44 & 16.28 \\
Distillers grains & 7.44 & 9.19 \\
Soybean meal & 7.36 & 7.89 \\
Whole cottonseeds & $\ldots$ & 14.95 \\
Mineral mix & 6.69 & 5.33 \\
Springer minerals & 10.70 & $\cdots$ \\
Bermuda hay & 0.59 & $\cdots$ \\
Trace minerals & 0.42 & $\cdots$ \\
Dicalcium phosphate & & $\cdots$ \\
Chemical composition & 56.54 & Percentage \\
DM & 15.28 & 63.77 \\
CP & 34.80 & 17.67 \\
Sol CP & 22.34 & 33.43 \\
ADF & 37.34 & 25.33 \\
NDF & 4.83 & 37.16 \\
Ether extract & 68.10 & 5.83 \\
TDN & 1.58 & 1.68 \\
NE (Mcal/kg) & & \\
\hline${ }^{1}$ Analyses of components from NEDHIA Forage Laboratory, Ithaca, \\
NY. & & \\
${ }^{2}$ DM basis. & & \\
${ }^{3}$ Percentage of the CP. & &
\end{tabular}

ous injections of $0.4 \mathrm{ml}$ of POSILAC biweekly. This volume of POSILAC contained approximately $142.9 \mathrm{mg}$ of $\mathrm{bST}$ and provided about $10.2 \mathrm{mg}$ of $\mathrm{bST} / \mathrm{d}$. Injections began approximately $21 \pm 3 \mathrm{~d}$ before expected calving dates. Regardless of day of last injection before calving, first postpartum injection was within $24 \mathrm{~h}$ of calving, and thereafter injections were at 2 -wk intervals. Last injection was at $42 \mathrm{~d}$ postpartum. Injections were subcutaneous in the postscapular region or the ischiorectal fossa and were administered after blood collection, but before a.m. feeding or milking. No injections of bST were given between $42 \mathrm{~d}$ postpartum and $100 \pm 4 \mathrm{~d}$ postpartum, but all cows received a full dose of POSILAC beginning at $100 \pm 4 \mathrm{~d}$ postpartum.

\section{Feeding Program}

Starting 4 wk before expected calving dates during both years, an anionic (-10 Meq/100 g DM) close-up dry cow ration was fed. After parturition, all cows were fed a TMR based on corn silage, whole cottonseeds, and grain concentrate (Table 1). Clean fresh water was available free choice in the free-stall barn where they were housed. Barns were equipped with fans and misters, which helped cool cows when ambient temperatures were above $25^{\circ} \mathrm{C}$. 


\section{Body Weights and Body Condition Scores}

Body weights and BCS ( 1 to 5 , thin to fat, recorded in 1/4-point intervals; Ferguson et al., 1994) of cows were recorded biweekly on the same day each week before a.m. feeding or milking (0800 to $1200 \mathrm{~h}$ ) during yr 2 only. Measurements began the day cows were assigned to trial and through $100 \mathrm{~d}$ postpartum. The BW and BCS of the cows at the time the trial started ranged from 504 to $870 \mathrm{~kg}$ and 3.00 to 4.75 , respectively. Cows that were dried when outside the recommended BCS (3.25 to 3.75) included $12 \mathrm{CON}$ cows and 16 TRT cows; 22 cows were within $1 / 4$ point of recommended, with only six cows $\geq 1 / 2$ point above recommended.

\section{Blood Collection, Handling, and Storage}

Blood samples were collected from the coccygeal vein of all cows before the a.m. feeding or milking (0730 to $1000 \mathrm{~h}$ ) during yr 1 only. Cows were bled the day they were assigned to the trial and biweekly during the prepartum period, the week of calving, and then at 4-wk intervals to about $60 \mathrm{~d}$ postpartum. For blood collection, Vacutainer-brand needles $(2.54 \mathrm{~cm}, 20$ gauge $)$ and tubes containing sodium heparin were used $(10-\times 100$ mm blood collection tubes, Becton-Dickinson, Fairlawn, $\mathrm{NJ})$. Blood samples were placed on ice immediately after collection and processed within $2 \mathrm{~h}$. All samples of blood were centrifuged at $3000 \mathrm{rpm}$ at $5^{\circ} \mathrm{C}$ for $30 \mathrm{~min}$ in an RC-3B refrigerated centrifuge (six-place swinging bucket, H-600A rotor, Sorvall Instruments, Du Pont, Wilmington, DE) to separate plasma. Plasma from each sample was aliquoted into two labeled 5-ml polyethylene tubes $(75 \times 12 \mathrm{~mm})$, capped, and frozen at $20^{\circ} \mathrm{C}$ until analyzed.

Plasma samples were analyzed for somatotropin (Garcia, 1998), insulin (Malven et al., 1987), and IGFI (Abribat et al., 1990) by specific radioimmunoassays. The in vitro enzymatic colorimetric method (NEFA C, Wako Pure Chemical Industries, Osaka, Japan) was used for the quantitative determination of NEFA in plasma as described by Johnson and Peters (1993). Sigma procedure no. 510 (Sigma Diagnostics, St. Louis, MO) was used for the quantitative enzymatic determination of glucose in deproteinized plasma samples as described by Raabo and Terkildsen (1960). The NEFA and glucose assays were carried out in 96-well flat bottom culture plates (Sarstedt, Newton, NC).

\section{Milking and Milk Collection}

Milk yields were recorded at each of the three daily milkings $(0830,1500$, and $0130 \mathrm{~h}$ ) from 3 to $100 \mathrm{~d}$ postpartum. Milk samples were collected at three consecutive milkings the same day each week during the first
10 wk of lactation. Milk samples were saved in capped vials $(50 \mathrm{ml})$ containing broad spectrum Microtab preservative (D\&F Control Systems, Inc., San Ramon, CA) and analyzed at Southeast Dairy Laboratory (McDonough, GA) for contents of fat, protein, MUN, and SCC.

\section{Statistical Analyses}

Data were analyzed as separate prepartum and postpartum datasets using the Proc Mixed procedure (Littell et al., 2000). Data analyzed were BW and BCS, milk and 3.5\% FCM yields, milk components, and concentrations of somatotropin, insulin, IGF-I, glucose, and NEFA in plasma. Time periods considered for data analyses were from 4 to $1 \mathrm{wk}$ prepartum, overall postpartum treatment period ( 1 to $8 \mathrm{wk}$ or to $10 \mathrm{wk}$ for BCS and BW), and the period from 3 to $100 \mathrm{~d}$ postpartum for MY. The following model was used to analyze data:

$$
\mathrm{Y}_{\mathrm{ijkL}}=+\mathrm{T}_{\mathrm{i}}+\mathrm{M}_{\mathrm{j}}+\mathrm{TM}_{\mathrm{ij}}+\mathrm{C}_{\mathrm{k}(\mathrm{ij})}+\mathrm{W}_{\mathrm{L}}+\varepsilon_{\mathrm{ijkl}}
$$

where

$$
\begin{aligned}
\mathrm{Y}_{\mathrm{ijkL}}= & \text { the effect calculated, } \\
\mu & =\text { overall mean, } \\
\mathrm{T}_{\mathrm{i}}= & \text { effect of ith treatment, } \\
\mathrm{M}_{\mathrm{j}}= & \text { effect of } \mathrm{jth} \text { calving month, } \\
\mathrm{TM}_{\mathrm{ij}}= & \text { interaction of treatment and calving } \\
& \text { month, } \\
\mathrm{C}_{\mathrm{k}(\mathrm{ij})}= & \text { kth cow in ith treatment and jth calving } \\
& \text { month, } \\
\mathrm{W}_{\mathrm{L}}= & \text { effect of Lth week or day, and } \\
\varepsilon_{\mathrm{ijkl}}= & \text { error. }
\end{aligned}
$$

Models included the main effects of TRT, calving month (CMO), the interaction (TRT*CMO), using cow within (TRT*CMO) as the error term, and weeks or days to the highest order significant for overall prepartum and postpartum periods, as appropriate.

\section{RESULTS}

\section{Body Weight and Body Condition Scores}

Changes in BW and BCS were evaluated during the prepartum period starting about 4 wk before parturition through 10 wk postpartum to identify when BW and BCS reached the nadir and then began to increase. The mean BW 3 to $4 \mathrm{wk}$ before calving of cows in CON did not differ significantly from cows receiving bST (706 \pm 12.9 vs. $727 \pm 11.9 \mathrm{~kg} ; P=0.45$; Figure 1). Mean BCS of cows were $3.71 \pm 0.06(\mathrm{CON})$ and $3.77 \pm 0.06$ (TRT) (Figure 2). During the period from 4 wk before until the day of calving no effects were detected due to TRT, 


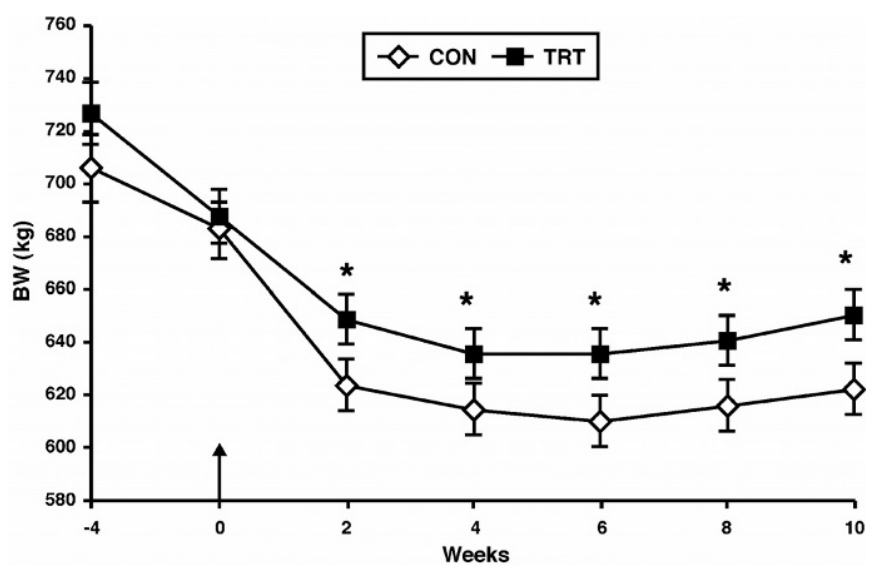

Figure 1. Least squares means and SE for BW of Holstein cows during the prepartum and early postpartum periods $(-4 \mathrm{wk}$ through $10 \mathrm{wk}$; calving $=$ wk 0 as indicated by arrow). Biweekly injections of bST (TRT) began 3 wk prepartum and continued through $42 \mathrm{~d}$ postpartum. Control cows $(\mathrm{CON})$ received no bST. Significant differences between TRT and CON indicated by *; $P \leq 0.06$.

CMO, or TRT*CMO for either BW or BCS, but significant linear effects of week were detected $(P<0.01)$.

During the overall postpartum period ( 1 to $10 \mathrm{wk}$ ), the effect of TRT on BW tended to be significant $(P=$ 0.08). Cows receiving bST better maintained their BW (Figure 1), but no effects were detected for CMO or TRT*CMO. A linear effect of week was detected for BW $(P<0.01)$. Even though cows in both treatments had similar BW the week after calving (wk 0;682 \pm 10.8 vs. $688 \pm 10.6 \mathrm{~kg}$ ), the loss in BW for cows in CON was greater during the postpartum period (Figure 1). At 2 wk after calving, cows in CON and TRT had lost an additional 8.5 and $5.6 \%$ of their BW, respectively, com-

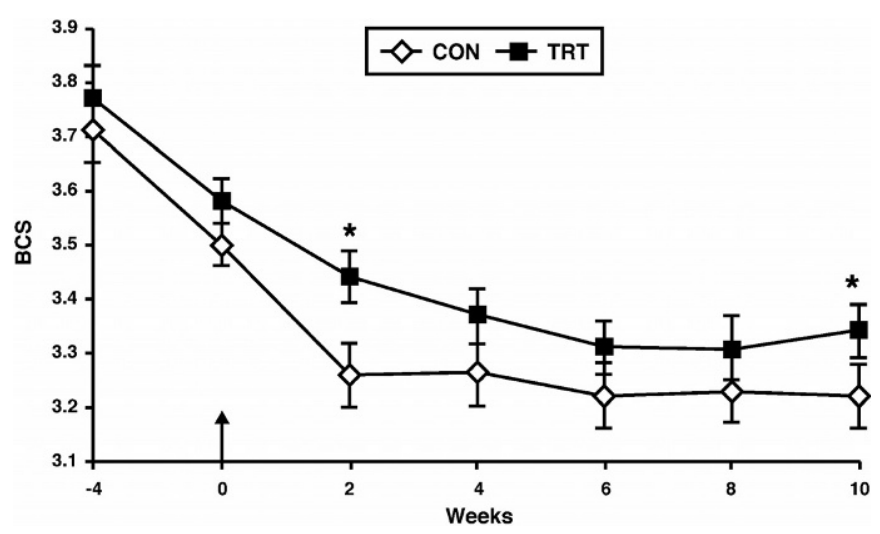

Figure 2. Least squares means and SE for BCS of Holstein cows during the prepartum and early postpartum periods $(-4$ wk through $10 \mathrm{wk}$; calving $=$ wk 0 as indicated by arrow). Biweekly injections of bST (TRT) began 3 wk prepartum and continued through $42 \mathrm{~d}$ postpartum. Control cows $(\mathrm{CON})$ received no bST. Significant differences between TRT and CON indicated by *; $P \leq 0.08$. pared with the week of calving. During the following 2 -wk period, extent of BW loss was less by cows in both groups. There was a slight but nonsignificant trend for $\mathrm{BW}$ to increase beginning at wk 6 or 8 for cows in both treatments. Overall, cows receiving bST maintained significantly greater BW throughout the 10 -wk lactation period ( $642 \pm 8.9$ vs. $617 \pm 9.0 \mathrm{~kg} ; P<0.07$; Figure 1 ).

Trends for BCS of cows in the two treatment groups paralleled those of BW (Figures 1 and 2). The BCS tended to differ during the lactation period $(P<0.15)$, but no effects of CMO or TRT*CMO were detected. Cows in both treatment groups lost BCS after calving (Figure 2), with decline slightly greater at wk 2 for cows in CON $(-6.8 \%)$ than cows in TRT $(-3.9 \%)$. At $6 \mathrm{wk}$ postpartum, cows had lost 8.0 and $7.5 \%$ of their BCS, respectively, compared with wk 0 . At wk 10, BCS of cows having received bST had increased slightly and was significantly greater than for control cows $(P<0.08$; Figure 2).

\section{Milk and 3.5\% FCM Yields}

Mean daily milk yields of cows during the first 100 $\mathrm{d}$ of yr 1 and 2 did not differ (38.9 vs. $38.2 \mathrm{~kg} / \mathrm{d}$, respectively; $P=0.46$ ). Differences in mean MY were detected due to treatment during the period from 3 to $60 \mathrm{~d}$. Cows receiving bST tended to have greater mean MY (6.6\%) than control cows, $($ TRT $=38.3 \pm 0.17 \mathrm{~kg} / \mathrm{d}$ vs. $\mathrm{CON}=$ $35.9 \pm 0.19 ; P<0.09$ ). No significant difference in any measure of milk production response was detected when cows that had BCS outside recommended range at drying were compared with all cows or when compared only with cows within the recommended BCS range. No effect was detected for CMO or TRT*CMO, but a significant curvilinear (quartic) effect of day was detected $(P<0.01)$.

Trends for differences $(P<0.1)$ were detected due to treatment for MY over $8 \mathrm{wk}$, from 3 to $60 \mathrm{~d}$, and for $3.5 \%$ FCM yield over 8 wk but not for MY through 100 DIM (Figures 3, 4, and 5). No effects were detected due to CMO or CMO*TRT for either measure of milk production. Cows receiving $10.2 \mathrm{mg}$ of bST/d (TRT) had greater weekly mean milk and $3.5 \%$ FCM yields $(39.7$ \pm 0.19 and $40.2 \pm 0.24 \mathrm{~kg} / \mathrm{d})$ than control cows $(37.2 \pm$ 0.22 and $37.7 \pm 0.27 \mathrm{~kg} / \mathrm{d}$; Figures 4 and 5). Milk and $3.5 \%$ FCM yields for bST-injected cows were 6.7 and $6.6 \%$ greater than controls, respectively. However, no difference in MY due to TRT was observed during first 100 DIM (Figure $3 ; 37.4 \pm 0.16$ vs. $39.1 \pm 0.17 \mathrm{~kg} / \mathrm{d}, P$ $=0.22$ ), which included $40 \mathrm{~d}$ when cows did not have any exposure to bST treatment (60 to $100 \mathrm{~d}$; $39.7 \pm 0.11$ vs. $40.3 \pm 0.13 \mathrm{~kg} / \mathrm{d}, P=0.7)$. No differences in least squares mean percentages of protein $(3.01 \pm 0.1 \mathrm{vs} .3 .01$ $\pm 0.1)$, fat $(3.60 \pm 0.02$ vs. $3.59 \pm 0.02)$, and MUN (11.6 


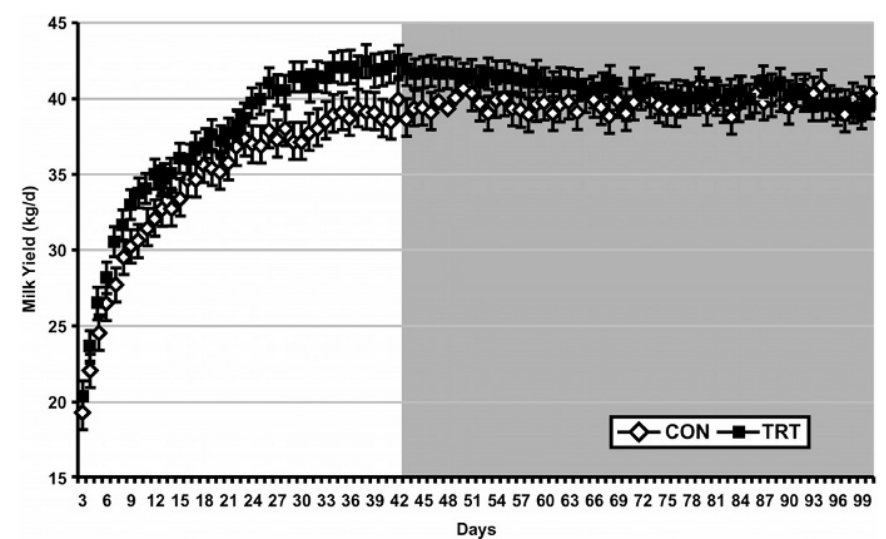

Figure 3.. Least squares means and SE for daily milk yields of Holstein cows during the first $100 \mathrm{~d}$ of lactation. bST injected (TRT) biweekly beginning 3 wk prepartum through $42 \mathrm{~d}$ postpartum. Control cows (CON) received no bST. Shaded area indicates time period with no bST.

\pm 0.1 vs. $11.7 \pm 0.09$ ) during first 8 wk were detected due to treatment, but mean SCC was numerically greater for cows in CON (602 \pm 33.2 vs. $453 \pm 29.2 \times$ $\left.10^{3} ; P=0.14\right)$. Overall, no prepartum or postpartum health problems, apparent calving problems, or differences in culling rates $(\mathrm{CON}=15$ vs. $\mathrm{TRT}=12$ cows $)$ were observed across the treatments for cows during the transition period or at the end of lactation.

\section{Hormones, Growth Factor, and Metabolites}

Prepartum. Mean concentrations of somatotropin at $21 \mathrm{~d}$ before calving did not differ for the two groups (6.1 \pm 0.42 for CON vs. $6.4 \pm 0.41 \mathrm{ng} / \mathrm{ml}$ for TRT; Figure 6 ). However, mean plasma concentration of somatotropin

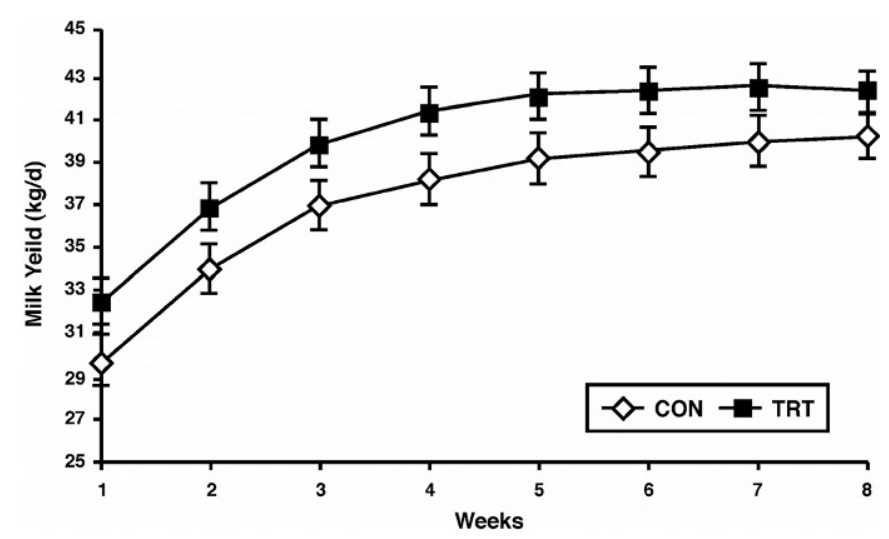

Figure 4. Least squares means and SE for weekly milk yields of Holstein cows during the first 8 wk of lactation. The bST injected (TRT) biweekly beginning 3 wk prepartum through $42 \mathrm{~d}$ postpartum. Control cows (CON) received no bST. All comparisons between TRT and CON differed; $P \leq 0.09$.

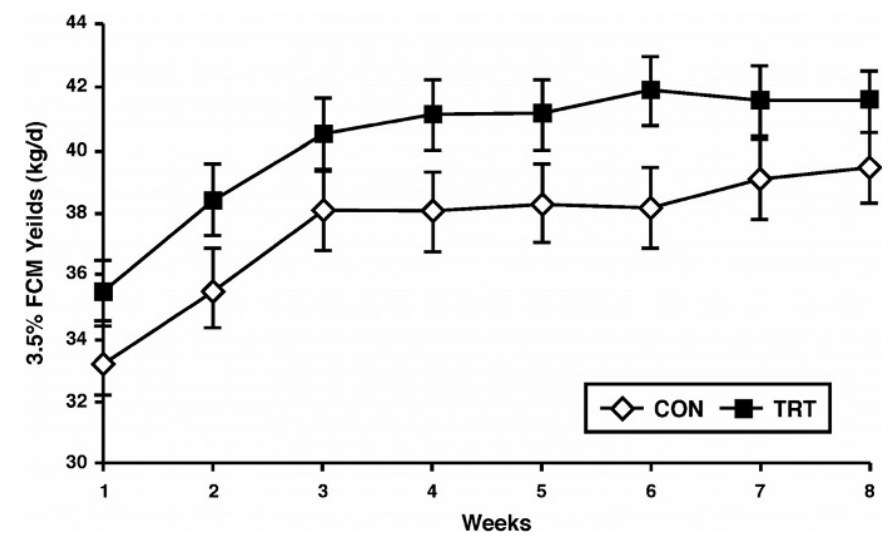

Figure 5. Least squares means and SE for weekly 3.5\% FCM yields of Holstein cows during the first $8 \mathrm{wk}$ of lactation. The bST injected (TRT) biweekly beginning 3 wk prepartum through $42 \mathrm{~d}$ postpartum. Control cows (CON) received no bST. All comparisons between TRT and CON differed; $P \leq 0.09$.

was greater for cows receiving bST during the overall prepartum period $(P<0.01)$. One week before calving, mean concentrations of somatotropin were greater $(\sim 87 \%)$ for cows in TRT than CON (12.7 \pm 0.81 vs. 6.8 $\pm 0.72 \mathrm{ng} / \mathrm{ml}$ ); concentrations of somatotropin for cows in CON were similar to those on d-21 (Figure 6). Across treatments, effects of CMO $(P=0.07)$ and week $(P<$ 0.01 ) but not TRT*CMO were detected during the prepartum period.

Mean plasma concentrations of IGF-I during the prepartum period did not differ due to treatment (Figure 7). Significant effects of CMO $(P<0.01)$ and week $(P<$ 0.05 ) were detected, but not for TRT*CMO. Cows in control and bST-injected groups had similar concentrations of IGF-I at $3 \mathrm{wk}$ before parturition (170.2 \pm 5.3

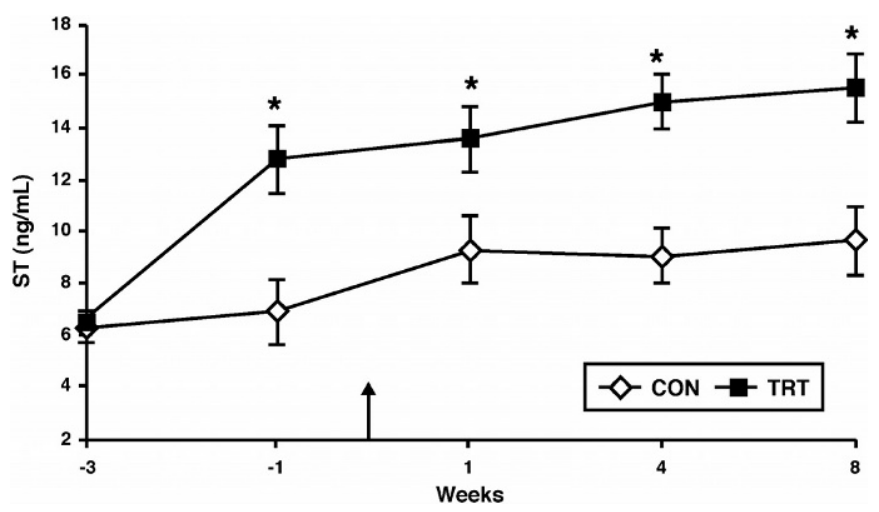

Figure 6. Least squares mean concentrations and SE for somototropin (ST) in plasma during the transition period and through 8 wk of lactation. The bST injected (TRT) biweekly beginning $3 \mathrm{wk}$ prepartum through $42 \mathrm{~d}$ postpartum. Control cows (CON) received no bST. Arrow indicates calving. Significant differences between TRT and CON indicated by *; $P<0.01$. 


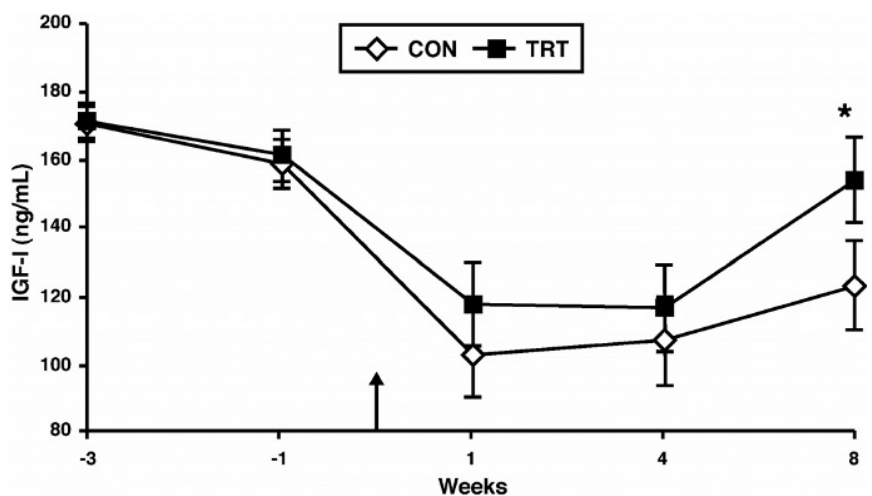

Figure 7. Least squares mean concentrations and SE for IGF-I in plasma during the transition period and through $8 \mathrm{wk}$ of lactation. The bST injected (TRT) biweekly beginning $3 \mathrm{wk}$ prepartum through $42 \mathrm{~d}$ postpartum. Control cows (CON) received no bST. Arrow indicates calving. Significant difference between TRT and CON indicated by *; $P<0.07$.

vs. $171.1 \pm 5.5 \mathrm{ng} / \mathrm{ml}$, respectively). Overall, concentrations of IGF-I decreased as parturition approached (1 wk prepartum) in both groups (156.4 \pm 5.9 and 160.9 $\pm 6.2 \mathrm{ng} / \mathrm{ml}$, respectively); decreases were 8.1 and $5.9 \%$ (Figure 7).

During the prepartum period, mean concentration of insulin in plasma tended to be greater in cows receiving bST $(P=0.08$; Figure 8$)$. Effect of week $(P=0.06)$ was detected, but neither CMO nor TRT*CMO were significant. Mean plasma concentrations of insulin tended to increase slightly ( 10\%) from $3 \mathrm{wk}$ before to $1 \mathrm{wk}$ before calving in the control group, but for cows in TRT the increase was greater by 1 wk before calving (26\%; Figure 8). Mean concentrations of glucose in plasma during

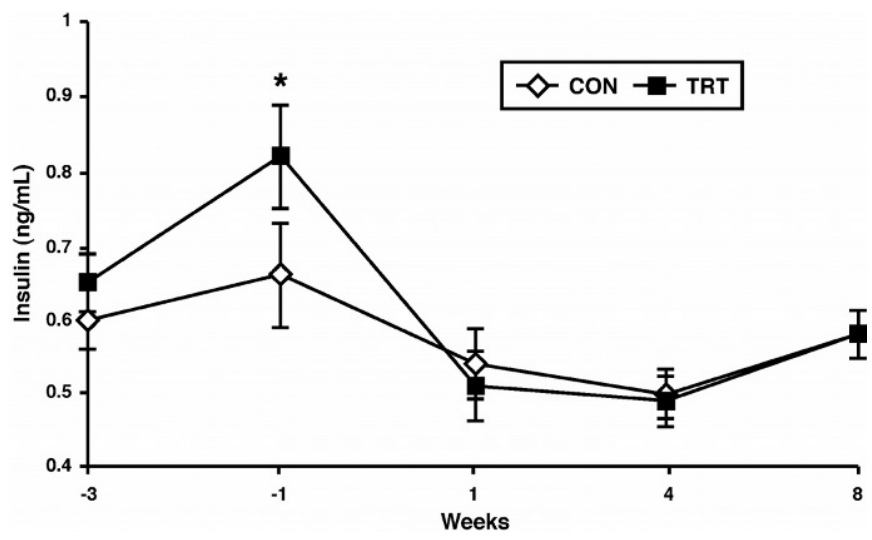

Figure 8. Least squares mean concentrations and SE for insulin in plasma during the transition period and through $8 \mathrm{wk}$ of lactation. The bST injected (TRT) biweekly beginning 3 wk prepartum through $42 \mathrm{~d}$ postpartum. Control cows (CON) received no bST. Arrow indicates calving. Significant difference between TRT and CON indicated by *; $P<0.05$.

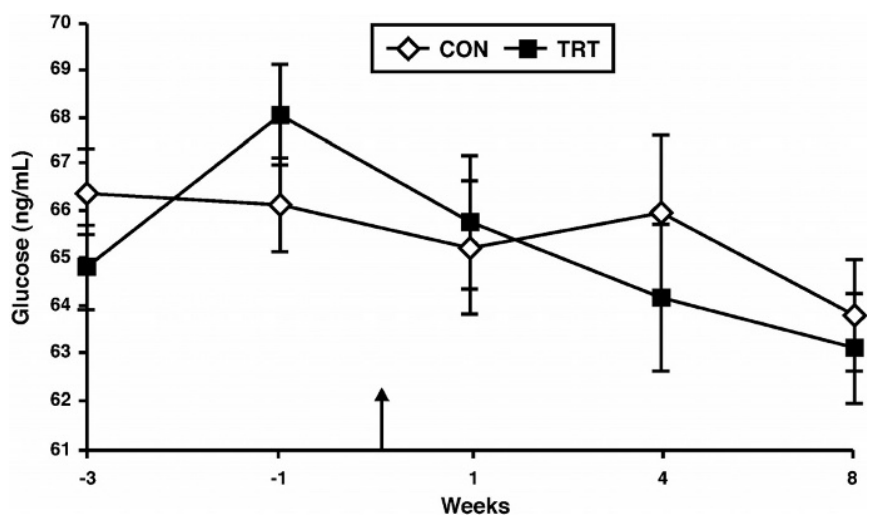

Figure 9. Least squares mean concentrations and SE for glucose in plasma during the transition period and through $8 \mathrm{wk}$ of lactation. The bST injected (TRT) biweekly beginning $3 \mathrm{wk}$ prepartum through 42 d postpartum. Control cows (CON) received no bST. Arrow indicates calving.

the prepartum period did not differ due to treatment $(66.3 \pm 0.7$ for CON vs. $66.4 \pm 0.7 \mathrm{mg} / \mathrm{dl}$ for TRT; Figure 9). No effects were detected due to CMO or TRT*CMO, but an effect of week was detected $(P=0.07)$. At 3 wk prepartum, concentrations of glucose were 66.4 and $64.8 \mathrm{mg} / \mathrm{dl}$ for cows in CON and TRT, respectively. Although the slight differences in concentrations between groups at 1 wk prepartum were not significant, the increase seen within the bST-injected group from 3 to 1 wk prepartum was significant $(P<0.05$; Figure 9$)$.

Mean concentrations of NEFA in plasma did not differ between treatments (Figure 10) during the prepartum period. However, effects were detected due to CMO $(P<0.01)$ and TRT ${ }^{*} \mathrm{CMO}(P<0.01)$, but not due to week. Plasma concentrations of NEFA tended to in-

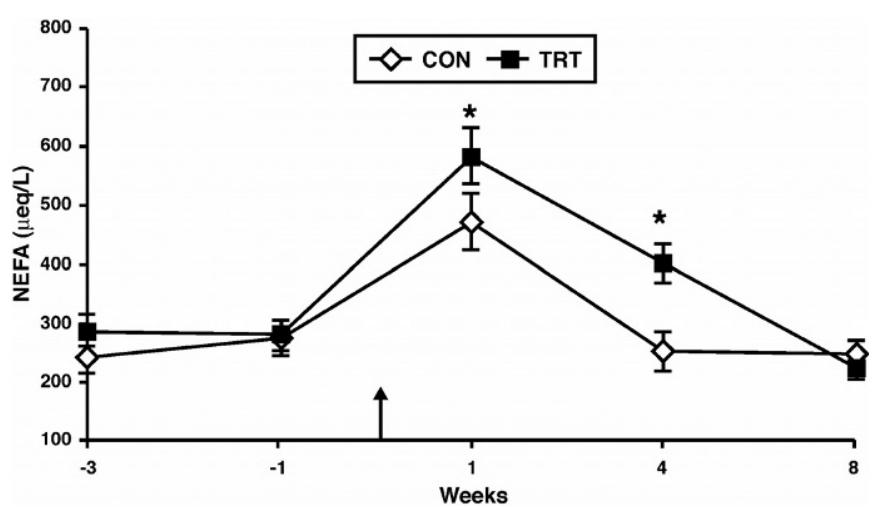

Figure 10. Least squares mean concentrations and SE for NEFA in plasma during the transition period and through $8 \mathrm{wk}$ of lactation. The bST injected (TRT) biweekly beginning $3 \mathrm{wk}$ prepartum through $42 \mathrm{~d}$ postpartum. Control cows (CON) received no bST. Arrow indicates calving. Significant differences between TRT and CON indicated by $* ; P \leq 0.05$. 
crease slightly (9.5\%) from 3 to $1 \mathrm{wk}$ prepartum for cows in $\mathrm{CON}$ (241.1 to $275.1 \mu \mathrm{Eq} / \mathrm{L}$ ), whereas they tended to decrease for cows in TRT (-3.5\%; 285.4 to $275.6 \mu \mathrm{Eq} /$ L; Figure 10).

Postpartum. Least squares means for concentrations of somatotropin postpartum differed significantly between treatment groups $(P<0.01)$. Cows receiving bST injections postpartum had greater concentrations of somatotropin $(14.6 \pm 0.84 \mathrm{ng} / \mathrm{ml})$ than did cows in CON $(9.3 \pm 0.86 \mathrm{ng} / \mathrm{ml})$, and they remained greater throughout this early postpartum period. After calving, mean concentrations of somatotropin in control cows increased then remained elevated (Figure 6), but no effects were detected due to CMO, week, or TRT*CMO.

Overall, mean plasma concentrations of IGF-I decreased following calving for cows in both CON $(-35 \%)$ and TRT $(-31 \%)$ and remained low at wk 4 . Differences between the treatments were not significant at wk 1 or 4. Mean concentrations of IGF-I increased at wk 8 in both CON (15\%) and TRT (32\%) but were numerically greater in TRT $(P=0.09$; Figure 7$)$. Significant effects of CMO $(P<0.05)$ and TRT $*$ CMO $(P=0.06)$ were detected, and a significant linear effect of week was observed $(P<0.05)$.

During the postpartum period mean concentrations of insulin in plasma did not differ between treatments and no effects of week, CMO, or TRT*CMO were detected. Plasma concentrations of insulin decreased significantly after parturition in both groups and had declined further at wk 4. By wk 8, concentrations of insulin in plasma had increased for cows in both $\operatorname{CON}(P<$ $0.08)$ and TRT $(P<0.05$; Figure 8$)$. For glucose, no significant effects of TRT, CMO, TRT*CMO, or week were detected during $8 \mathrm{wk}$ postpartum. Cows in both treatment groups showed stable or slightly decreased plasma concentrations of glucose after parturition, and they remained lower as lactation progressed (Figure 9).

Least squares means for concentrations of NEFA during the first 8 wk postpartum for TRT groups differed significantly $(P<0.01)$ and also due to week $(P<0.01)$, $\mathrm{CMO}(P=0.06)$, and TRT $* \mathrm{CMO}(P<0.01)$. After calving, mean concentrations of NEFA increased for cows in both groups, but cows in TRT tended to have greater $(\sim 23 \%)$ mean concentrations of NEFA $(579.8 \mu \mathrm{Eq} / \mathrm{L})$ than cows in CON $(470.0 \mu \mathrm{Eq} / \mathrm{L})$. By wk 8, concentrations had declined in both groups, but no difference was observed between them $(\mathrm{CON}=249.2$ vs. $\mathrm{TRT}=222.2$ $\mu \mathrm{Eq} / \mathrm{L}$; Figure 10).

\section{DISCUSSION}

One important objective of this experiment was to evaluate changes in BW and BCS from about $4 \mathrm{wk}$ prepartum through 10 wk postpartum. Reports by Gu- lay et al. (2000) and Garcia (1998) indicated that cows receiving injections of bST postpartum better maintained BCS than cows not receiving bST and treated cows also started recovering BCS earlier during the postpartum period. Also, cows receiving bST during both prepartum and postpartum periods had less pronounced losses in BW than cows not treated with bST (Garcia, 1998). Although prepartum BW and BCS of cows did not differ between the treatment groups in the current study, cows receiving bST did maintain their BW and BCS better than control cows following parturition. Recovery of BCS and gain in BW started at wk 6 for both groups, but cows receiving bST maintained greater BW from wk 2 through wk 10 postpartum (Figures 1 and 2).

Rapid and high rate of increase in DMI during early lactation is essential to provide energy and nutrients to support the rapid increase in milk yield. In earlier studies, cows treated with bST (5 and $14 \mathrm{mg} / \mathrm{d}$ ) during the previous lactation, but not throughout the dry period, had greater DMI during the subsequent earlylactation period (Lean et al., 1991). Dry matter intake tended to increase about $3 \mathrm{~kg} / \mathrm{d}$ more in bST-treated cows (5 and $14 \mathrm{mg} / \mathrm{d}$ ) after parturition (Simmons et al., 1994). Gulay et al. (2000) also showed that greatest increases in DMI were by cows injected with $15.3 \mathrm{mg}$ of bST/d during the first $21 \mathrm{~d}$ postpartum. Even though no direct measure of DMI was made during the current experiment, changes in both BW and BCS following parturition suggested that cows treated with $10.2 \mathrm{mg}$ of bST/d had greater DMI during the transition period and early lactation. This interpretation also was supported by the responses seen in milk production.

Milk production was increased significantly by prepartum and postpartum bST injections. Increases in both milk and 3.5\% FCM yields were about 6.6\% throughout the injection period and were similar to the $6 \%$ increase reported by Stanisiewski et al. (1992) in a study in which cows received either 5 or $14 \mathrm{mg}$ of bST/ $\mathrm{d}$ from 14 through $60 \mathrm{~d}$ postpartum. Moreover, in that study, cows receiving the lower dose had higher conception and pregnancy rates than all other experimental cows, and they also maintained BCS as well as controls. In contrast, Eppard et al. (1996) failed to increase MY of Holstein and Jersey cows that received a full dose of POSILAC during $28 \mathrm{~d}$ of the prepartum period. However, cows in that study also were used for milk fever induction, which may have affected MY responses. When cows received $20.6 \mathrm{mg}$ of bST/d starting 4 to $9 \mathrm{~d}$ postpartum, no significant differences were detected in MY of control or bST-treated cows (de Boer et al., 1991). Unfortunately, the cows assigned to bST had lower MY potential than controls based on the rate and extent of decline in MY after cessation of bST injection. In an- 
other trial, Bachman et al. (1992) concluded that milk and $3.5 \%$ FCM yields of treated and control cows did not differ due to prepartum injections of $25 \mathrm{mg}$ of bST/ d. However, bST treatment failed to increase concentrations of somatotropin and IGF-I in the peripheral circulation in that study. On the other hand, Gulay et al. (2000) reported numerically, but not significantly greater mean daily milk production when cows received either 10.2 or $15.3 \mathrm{mg}$ of $\mathrm{bST} / \mathrm{d}$ beginning prepartum and continuing through $\sim 60 \mathrm{~d}$ postpartum. When cows were injected with greater amounts of bST $(500 \mathrm{mg} / 14$ d) starting $28 \mathrm{~d}$ before expected calving date through parturition, they produced $3.3 \mathrm{~kg} / \mathrm{d}$ more milk than uninjected controls during the first $42 \mathrm{~d}$ of lactation (Putnam et al., 1999).

In the current study, the treatment group that had the greater BW and BCS during early lactation also had the greatest milk yield. Even though cows receiving bST had the highest milk production, their BW tended to be greater $(P=0.08$; Figure 1$)$. It was concluded that milk production was supported to greater extent by increased DMI than by more extensive tissue mobilization to provide the energy and precursors to support lactation because they also lost less body condition during this time period (Figures 1 and 2). Moallem et al. (2000) reached a similar conclusion for cows that received bST injections during early lactation. However, DMI of their cows increased less than necessary to support milk production because they had an extensive period of negative energy balance (NEB).

Previous studies showed that low doses of bST had positive effects on concentrations of various hormones and metabolites when bST was administered from approximately $21 \mathrm{~d}$ prepartum through $\sim 60 \mathrm{~d}$ postpartum (Garcia et al., 2000; Gulay et al., 2000). In the current experiment, cows treated with bST had greater concentrations of somatotropin than control cows, and they remained greater throughout the early postpartum period (Figure 6), which agreed with Bauman and Vernon (1993) and Bachman et al. (1992). Prepartum injections of 5 and $14 \mathrm{mg}$ of bST/d increased plasma concentrations of somatotropin that remained elevated during the prepartum period ( 6.5 and $22.7 \mathrm{ng} / \mathrm{ml}$, respectively), whereas untreated cows maintained low concentrations $(1.6 \mathrm{ng} / \mathrm{ml})$ during the same period (Simmons et al., 1994).

Effects of somatotropin on regulation of IGF-I secretion and concentrations in plasma are well documented (Cohick et al., 1989; Bauman, 1992; Butler and Le Roith, 2001). Synthesis, release, and circulating concentrations of IGF-I are positively associated with secretion of somatotropin and injections of bST increased concentrations of IGF-I during both early and late lactation (Staples and Head, 1988; Lucy et al., 1993). Cows receiving either 10.2 or $15.3 \mathrm{mg}$ of $\mathrm{bST} / \mathrm{d}$ also had greater concentrations of IGF-I than control cows that were not treated after parturition (Gulay et al., 2000), and the IGF-I response to bST was greater when cows were in positive energy balance (Vicini et al., 1991; Bachman et al., 1992). The current study failed to detect an expected increase in concentrations of IGF-I during the prepartum period. This may have occurred because of infrequent sampling of blood (only once at 1-wk prepartum after bST treatments) and/or too short of a treatment period to detect an increase in plasma concentrations of IGF-I, even if it had occurred. Additionally, sampling times close to parturition would be expected to show reduced concentrations of IGF-I that typically occur then. Indeed, although concentrations of somatotropin in plasma remained elevated during the last week of pregnancy, plasma concentrations of IGF-I were less around parturition (Figure 7) and after calving in both groups of cows regardless of treatment, which agreed with results of Breier et al. (1988) and McGuire et al. (1992).

Changes seen for somatotropin and IGF-I were similar to that of Simmons et al. (1994) and likely were associated with reduced nutrient intake. Restriction of DMI in growing steers decreased the basal concentration of IGF-I in blood and terminated the positive response of IGF-I to exogenous somatotropin treatment as the response was uncoupled from somatotropin due to reduced DMI and energy balance (Breier et al., 1988). Low concentrations of IGF-I in blood during early lactation also were associated with low DMI and NEB during this period (Ronge et al., 1988; Vicini et al., 1991). Thus, the increase in circulating concentrations of IGF-I in bST-injected cows after calving might indicate better nutritional status. It also is possible that a reduced expression of the mRNA associated with somatotropin action in liver (GHR1A) during the transition period (Lucy et al., 2001) caused a decrease in the magnitude of somatotropin stimulation of IGF-I secretion and, thus, a reduced ability to maintain or increase circulating concentrations of IGF-I. Although there was a decrease in concentrations of IGF-I for cows in both treatment groups in the current study, mean concentrations of IGF-I for cows in TRT were significantly greater than for cows in CON at wk $8(P<0.07$; Figure 7$)$. Thus, bST apparently was able to stimulate IGF-I synthesis and release from the liver during the transition period and early lactation.

During the prepartum period, mean concentrations of insulin in plasma were significantly greater in cows receiving bST, but concentrations in both groups of cows did show a decrease after calving (Figure 8). Vicini et al. (1991) reported increased concentrations of insulin during late lactation and the dry period when bST was 
injected. Insulin concentrations of cows injected with 10.2 or $15.3 \mathrm{mg}$ of $\mathrm{bST} / \mathrm{d}$ also were greater than in control cows during the prepartum period (Gulay et al., 2000). High concentrations of insulin in blood were associated with positive energy balance of the cows that had greater DMI; a change that also promoted higher concentrations of glucose in blood during the dry period. However, during the postpartum period, mean concentrations of insulin in plasma declined in two groups of cows that were in NEB (Vicini et al., 1991). The decline we observed in insulin concentrations agreed with previous findings (Malven et al., 1987; Garcia, 1998; Gulay, 1998). Decreases in insulin receptors and concentrations of insulin following parturition result in depression of lipogenesis (Mepham, 1987). Despite the reduced concentrations of insulin, the number of insulin receptors increase in mammary tissue at parturition (Petterson et al., 1993). In addition, during late pregnancy, increased resistance to insulin causes a decrease in response to insulin in adipose tissue such that lipolysis and mobilization of NEFA are increased.

Overall, actions of somatotropin on insulin during the dry period should result in greater availability of glucose to support milk synthesis during the upcoming lactation. Although the current study failed to detect a significant difference in prepartum concentrations of glucose between treatments, the increase seen by $1 \mathrm{wk}$ prepartum for cows in TRT (Figure 9) was significant within that group. Somatotropin may have had a positive effect on prepartum plasma glucose concentrations at the time increased plasma concentrations of insulin also were seen. Changes may have been effected directly via increased hepatic gluconeogenesis or indirectly by antagonistic effects of somatotropin on insulin actions. Early lactation is characterized by low concentrations of insulin and a high somatotropin:insulin ratio. Somatotropin reduces the ability of insulin to inhibit gluconeogenesis, and it also inhibits both insulin uptake by the cell and the insulin protease necessary for the action of insulin (McNamara and Hillers, 1986; Marinchenko et al., 1992; McNamara 1995). Studies in vivo (Cohick et al., 1989) and in vitro (Knapp et al., 1992) have demonstrated that hepatic rates of gluconeogenesis were increased during treatment of dairy cows with bST. Pyruvate carboxylase (PC) and phosphoenolpyruvate carboxykinase are potential rate-limiting enzymes for hepatic gluconeogenesis during the transition period (Greenfield et al., 2000). Although Pershing et al. (2002) concluded bST stimulation of milk production was not mediated through enhanced liver gluconeogenesis in cows at $80 \mathrm{DIM}$, it was speculated that exogenous somatotropin would increase the synthesis of mRNA in the liver that coded for $\mathrm{PC}$ and phosphoenolpyruvate carboxykinase (Bauman, 1999). These changes would increase glucose production via gluconeogenesis, and priority use of glucose by mammary tissues could occur.

No significant effects of bST on concentrations of glucose in plasma were detected during postpartum period, but reduced concentrations of glucose in plasma after parturition were observed for cows in both groups (Figure 9). However, MY of cows in TRT averaged $2 \mathrm{~kg} / \mathrm{d}$ more than for cows in CON. This suggests that there was a higher rate of gluconeogenesis and/or nutrient availability in the bST-injected cows because of greater DMI during early postpartum period. These changes would support increased MY by providing energy and precursors needed for milk synthesis. Infrequent sampling of blood may have been one factor contributing to failure to detect changes in plasma concentrations of glucose during lactation. Clearly, greater amounts of glucose were needed to support the increase in milk production observed.

Mean concentration of NEFA did not differ significantly between treatment groups during the prepartum period, and no significant increase in concentrations of NEFA in plasma was observed for either treatment group. However, during the postpartum period a different pattern was observed. Although cows in both groups increased mean concentrations of NEFA after calving, cows receiving bST had numerically greater mean concentrations early in the postpartum period. However, concentrations of NEFA declined in both groups of cows after wk 1 postpartum and were slightly less than prepartum concentrations by wk 8 postpartum (Figure 10). As mentioned previously, lactation is characterized by low concentrations of insulin and a high somatotropin:insulin ratio, and decreased insulin receptors in liver. As a consequence, there is depression of lipogenesis (Mepham, 1987), increased lipolysis, and NEFA mobilization (Petterson et al., 1993). Bell (1995) concluded that a combination of metabolic changes such as a decrease in de novo synthesis of triglyceride, increased lipolysis, reesterification of fatty acids in the adipose tissue, and reduced intracellular reesterification of fatty acids arising from lipolysis might cause increased mobilization of NEFA. High concentrations of NEFA in plasma also are associated with actions of some metabolic hormones. For example, high concentrations of somatotropin in plasma during late pregnancy may reduce insulin receptors on adipocytes, inhibit the action of a second messenger, or inhibit the insulin protease required for action of insulin ( $\mathrm{McNa}$ mara and Hillers, 1986), changes that decrease rates of lipogenesis. Thus, somatotropin can be considered a major regulator of metabolic adaptations during the transition period (Marinchenko et al., 1992; McNamara, 1995). 


\section{CONCLUSIONS}

Injecting a low dose of bST (10.2 mg/d) during the transition period resulted in better maintenance of $\mathrm{BW}$ and earlier recovery of BCS during early lactation with no greater NEB. Cows receiving bST produced significantly more milk and 3.5\% FCM during the injection period. Changes in concentrations of metabolic hormones likely resulted in positive effects that caused increased DMI as reflected by the BW, BCS, and MY patterns seen for bST-injected cows. No carryover effects of bST on MY were detected after injections were discontinued $\sim 42 \mathrm{~d}$ postpartum because the increase in MY did not persist beyond $60 \mathrm{~d}$. Thus, it appears that cows could be treated with low doses of bST to improve $\mathrm{MY}$, even if they were to receive a full dose of bST (500 mg of bST/14 d) later in the lactation (after $60 \mathrm{~d}$ ). Further studies are justified to evaluate the effect of timing of bST injections on DMI, subsequent production and health measures, and to identify the relative benefits of prepartum versus postpartum bST.

\section{REFERENCES}

Abribat, T. H., H. Lapierre, P. Dubreuil, G. Pelletier, P. Gaudreau, P. Brazeau, and D. Petitclerc. 1990. Insulin-like growth factor-1 concentration in Holstein female cattle: Variations with age, stage of lactation and growth hormone-releasing factor administration. Domest. Anim. Endocrinol. 7:93-103.

Bachman, K. C., D. H. Wilfond, H. H. Head, C. J. Wilcox, and M. Singh. 1992. Milk yields and hormone concentrations of Holstein cows in response to Sometribove (Somatotropin) treatment during the dry period. J. Dairy Sci. 75:1883-1890.

Bauman, D. E. 1992. Bovine somatotropin: Review of an emerging animal technology. J. Dairy Sci. 75:3432-3451.

Bauman, D. E. 1999. Bovine somatotropin and lactation: From basic science to commercial application. Domest. Anim. Endocrinol. 17:101-116.

Bauman, D. E., P. J. Eppard, M. J. Gegeeter, and G. M. Lanza, 1985. Responses of high-producing dairy cows to long term treatment with pituitary somatotropin and recombinant somatotropin. J. Dairy. Sci. 68:1352-1362.

Bauman, D. E., and R. G. Vernon. 1993. Effects of bovine somatotropin on lactation. Annu. Rev. Nutr. 13:437-461.

Bell, A. W. 1995. Regulation of organic nutrient metabolism during transition from late pregnancy to early lactation. J. Anim. Sci. 73:2804-2819.

Breier, B. H., P. D. Gluckman, and J. J. Bass. 1988. The somatotropic axis in young steers: Influence of nutrition and estradiol-17 $\beta$ on hepatic high and low affinity somatotropic binding sites. J. Endocrinol. 116:169-177.

Butler, A. A., and D. Le Roith. 2001. Control of growth by the somatotropic axis: Growth hormone and insulin-like growth factors have related and independent roles. Annu. Rev. Physiol. 63:141-164.

Cohick, W. S., K. Plaut, S. J. Sechen, and D. E. Bauman. 1989. Temporal pattern of IGF-I response to exogenous GH in lactating cows. Domest. Anim. Endocrinol. 6:263-273.

deBoer, G., P. H. Robinson, and J. J. Kennelly. 1991. Hormonal responses to bovine somatotropin and dietary protein in early lactation dairy cows. J. Dairy Sci. 74:2623-2632.

Eppard, P. J., J. J. Veenhuizen, W. J. Cole, P. G. Comens-Keller, G. F. Hartnell, R. L. Hintz, L. Munyakazi, P. K. Olsson, R. H. Sorbet, T. C. White, C. A. Baile, R. J. Collier, J. P. Goff, and R. L Horst. 1996. Effect of bovine somatotropin administered to peripartur- ient dairy cows on the incidence of metabolic disease. J. Dairy Sci. 79:2170-2181.

Ferguson, J. D., D. T. Galligan, and N. Thomsen. 1994. Principal descriptors of body condition score in Holstein cows. J. Dairy Sci. 77:2695-2703.

Garcia, A. G. 1998. Use of bST in management of growing heifers and transition cows to improve growth rates and milk production. $\mathrm{Ph}$. D. dissertation. University of Florida, Gainesville.

Garcia, A. G., M. S. Gulay, M. J. Hayen, C. J. Wilcox, T. I. Belloso, and H. H. Head. 2000. Responses of Holstein cows to prepartum and postpartum injections of bovine somatotropin (bST). J. Dairy Sci. 83(Suppl. 1):220. (Abstr.)

Greenfield, R. B., M. J. Cecava, and S. S. Donkin. 2000. Changes in mRNA expression for gluconeogenic enzymes in liver of dairy cattle during the transition to lactation. J. Dairy Sci. 83:12281236.

Gulay, M. S. 1998. Physiological responses of Holstein cows to various bST treatments during the transition period. Master's thesis. University of Florida, Gainesville.

Gulay, M. S., A. G. Garcia, M. J. Hayen, C. J. Wilcox, and H. H. Head. 2000. Physiological responses of Holstein cows to various bST treatments during the transition period. J. Dairy Sci. (Suppl. 1):219. (Abstr.)

Johnson, M. M., and J. P. Peters. 1993. Technical note: An improved method to quantify nonesterified fatty acids in bovine plasma. J. Anim. Sci. 71:753-756.

Knapp, J. R., H. C. Freetly, B. L. Reis, C. C. Calvert, and R. L. Baldwin. 1992. Effects of somatotropin and substrates on patterns of liver metabolism in lactating dairy cattle. J. Dairy Sci. 75:1025-1035.

Lean, I. J., H. F. Troutt, M. L. Bruss, T. B. Farver, R. L. Baldwin, J. G. Galland, D. Kratzer, and L. D. Weaver. 1991. Postparturient metabolic and production responses in cows previously exposed to long term treatment with somatotropin. J. Dairy Sci. 74:3429-3445.

Littell, R. C., G. A. Milliken, W. W. Stroup, and R. D. Wolfinger. 2000. SAS system for mixed models. SAS Institute Inc., Cary, NC.

Lucy, M. C., R. L. de la Sota, C. R. Staples, and W. W. Thatcher. 1993. Ovarian follicular populations in lactating dairy cows treated with bovine somatotropin (sometribove) or saline and fed diets differing in fat content and energy. J. Dairy Sci. 76:1014-1027.

Lucy, M. C., H. Jiang, and Y. Kobayashi. 2001. Changes in the Somatotropic Axis associated with the initiation of lactation. J. Dairy Sci. 84(E. Suppl.):E113-E119.

Malven, P. V., H. H. Head, R. J. Collier, and F. C. Buonomo. 1987. Periparturient changes in secretion and mammary uptake of insulin and in concentrations of insulin and insulin like growth factors in milk of dairy cows. J. Dairy Sci. 70:2254-2265.

Marinchenko, G. V., J. P. McNamara, D. Sun, and B. Becker-Khaleel. 1992. Growth hormone alters metabolic effects and proteolysis of insulin in adipose tissue during lactation. Proc. Soc. Exp. Biol. Med. 200:57-66.

McGuire, M. A., J. L. Vicini, D. E. Bauman, and J. J. Veenhuizen. 1992. Insulin like growth factors and binding proteins and their nutritional regulation. J. Anim. Sci. 70:2901-2910.

McNamara, J. P. 1995. Role and regulation of adipose tissue metabolism during lactation. J. Nutr. Biochem. 6:120-129.

McNamara, J. P., and J. K. Hillers. 1986. Adaptation in lipid metabolism of bovine adipose tissue in lactogenesis and lactation. J. Lipid Res. 27:150-157.

Mepham, T. B. 1987. Neuroendocrine control of lactation. Page 109 in Physiology of Lactation. Open University Press, Philadelphia, PA.

Moallem, U., M. Kaim, Y. Folman, and D. Sklan. 1997. Effect of calcium soaps of fatty acids and administration of somatotropin in early lactation on productive and reproductive performance of high producing dairy cows. J. Dairy Sci. 80:2127-2136.

Moallem, U., M. Kaim, Y. Folman, and D. Sklan. 2000. Effects of somatotropin and dietary calcium soaps of fatty acids in early lactation on milk production, dry matter intake, and energy balance of high yielding dairy cows. J. Dairy Sci. 83:2085-2094.

Pershing, R. A., S. D. Moore, A. C. Dinges, W. W. Thatcher, and L. Badinga. 2002. Hepatic gene expression for gluconeogenic en- 
zymes in lactating dairy cows treated with bovine somatotropin. J. Dairy Sci. 85:504-506.

Petterson, J. A., F. R. Dunshea, R. A. Ehrhardt, and A. W. Bell. 1993. Pregnancy and undernutrition alter glucose metabolic response to insulin in sheep. J. Nutr. 123:1286-1295.

Putnam, D. E., G. A. Varga, and H. M. Dann. 1999. Metabolic and production responses to dietary protein and exogenous somatotropin in late gestation dairy cows. J. Dairy Sci. 82:982-995.

Raabo, E., and T. C. Terkildsen. 1960. The enzymatic determination of blood glucose. Scand. J. Clin. Lab. Invest. 12:402-408.

Ronge, H., J. Blum, C. Clement, F. Hans, and H. Binder. 1988. Somatomedin $\mathrm{C}$ in dairy cows related to energy and protein supply and to milk production. Anim. Prod. 47:165-183.

Simmons, C. R., W. G. Bergen, M. J. VandeHaar, D. J. Sprecher, C. J. Sniffen, E. P. Stanisiewski, and H. A. Tucker. 1994. Protein and fat metabolism in cows given somavubove before parturition. J. Dairy Sci. 77:1835-1847.

Stanisiewski, E. P., L. F. Krabill, and J. W. Lauderdale. 1992. Milk yield, health, and reproduction of dairy cows given somatotropin (somavubove) beginning early postpartum. J. Dairy Sci. 75:2149-2164

Staples, C. R., and H. H. Head. 1988. Short-term administration of bovine somatotropin to lactating dairy cows in a subtropical environment. J. Dairy Sci. 71:3274-3282.

Stelwagen, K., D. G. Grieve, and B. W. McBride. 1991. Growth and subsequent lactation in primigravid Holstein heifers after prepartum bovine somatotropin treatment. J. Dairy Sci. 75:463-471.

Vicini, J. L., F. C. Buonomo, J. J. Veenhuizen, M. A. Miller, D. R. Clemmons, and R. J. Collier. 1991. Nutrient balance and stage of lactation affect responses of insulin, insulin-like growth factors I and II, and insulin-like growth factor-binding protein 2 to somatotropin administration in dairy cows. J. Nutr. 121:1656-1664. 